\title{
Морфотипы кварталов исторического центра Санкт-Петербурга
}

\author{
Л.П.Лавров, СПбГАСУ, Санкт-Петербург \\ Е.Г.Молоткова, СПбГАСУ, Санкт-Петербург \\ Ф.В.Перов, СПбГАСУ, Санкт-Петербург
}

Отмечается, что в современном российском градостроительстве повысился интерес к потенциалу квартальной застройки, и в этой связи предлагается учесть опыт функционирования жилой среды этого типа в провинициальных городах, где она активно внедрялась со второй половины XVIII века. Самым крупным объектом исследования может стать сформированный по правилам «генетического кода» исторический центр Санкт-Петербурга, который сейчас рассматривается как единый «средовый район». Отмечается, что проводившиеся исследования исторического центра концентрировали внимание на эстетике, оставляя в тени внутриквартальные территории в значительной степени из-за того, что активная градостроительная деятельность здесь прекратилась сто лет назад. Обращение к конкретному уровню отдельного квартала позволяет уточнить представление о «завершённости» исторической среды. Предлагается учесть объективные показатели сложившейся застройки и на этой базе провести дифференцирование огромной территории, выделить характерные морфотипы. Приводятся данные, которые позволяют выделить две основные зоны - бывший «город» и бывшие пригороды и предместья. Выявляются характерные показатели исторической застройки Санкт-Петербурга в зависимости от местоположения территориальной единицы. Приводятся примеры, которые позволяют заключить, что застройка, осуществлённая в Санкт-Петербурге во второй половине XIX - начале XX века, привела к формированию весьма разнообразной городской среды, и каждый из возникших кварталов обладает значительными функционально-планировочными особенностями. Отмечается, что при выделении признаков «петербургских морфотипов» целесообразно учитывать не только собственную пространственную организацию кварталов, но и характер их связей с городским транспортно-пешеходным каркасом.

Ключевые слова: архитектура Санкт-Петербурга, исторический центр, жилая среда, морфотипы.

\section{Morphotypes of quarters of the historical center of St. Petersburg}

L.P.Lavrov, SPSUACE, St. Petersburg

E.G.Molotkova, SPSUACE, St. Petersburg

F.V.Perov, SPSUACE, St. Petersburg

It is noted that in modern Russian urban planning interest to the potential of quarterly development has increased, and in this regard it is proposed to take into account the experience of the functioning of this type of residential environment in provincial cities, where it has been actively introduced since the second half of the 18th century. The largest object of research may be the historical center of St. Petersburg, formed according to the rules of the "genetic code", which is now considered as a single "environmental area". It is noted that the conducted research of the historical center focused on aesthetics, leaving in the shadows inner-quarter territories, largely due to the fact that active urban planning stopped here a hundred years ago. Turning to the specific level of a particular quarter allows us to clarify the idea of the "completeness" of the historical environment. It is proposed to take into account the objective indicators of the existing development and on this basis to differentiate a vast territory, to highlight characteristic morphotypes. The presented data allow us to distinguish two main areas - the former "city" and the former suburbs and outskirts. The characteristic indicators of the historical buildings of St. Petersburg are identified depending on the location of the territorial unit. Examples that allow us to conclude that the development carried out in St. Petersburg in the second half of the XIX - early XX centuries led to the formation of a very diverse urban environment are given, and each of the arising quarters has significant functional and planning features. It is noted that when identifying the signs of "St. Petersburg morphotypes" it is advisable to take into account not only their spatial organization of the quarters but also the nature of their ties with the urban transport and pedestrian framework.

Keywords: architecture of St. Petersburg, historical center, living environment, morphotypes.

Общая площадь исторического центра Санкт-Петербурга составляет 5356,8518 га [1]. На жилые кварталы, по некоторым подсчётам, приходится 2114 га [2]. Проводившиеся исследования исторического центра концентрировали внимание на эстетике, оставляя в тени внутриквартальные территории, тем более что активная градостроительная деятельность здесь прекратилась сто лет назад и, следовательно, отсутствовали побудительные стимулы. Региональные нормативы используют самое общее представления о городском ядре - особенности каждой из 149 территориальных единиц не обсуждаются, и весь исторический центр рассматривается как единый «средовый район»${ }^{1}$. Специ-

${ }^{1}$ «Средовый район - участок городской среды, имеющий своеобразные архитектурно-художественный облик, структуру планировки и застройки, функции и интенсивность жизнедеятельности» (ТСН 30-306-2002 Территориальные строительные нормы. Реконструкция и застройка исторически сложившихся районов Санкт-Петербурга. - СПб : Стройиздат СПб, 2003 - 71 с.). 
алисты и широкая общественность разделяют мнение, что среду исторического центра надо считать сложившейся, завершённой, а изменение её параметров - невозможно [3].

Однако центр динамичной пятимиллионной метрополии не может находиться в летаргическом сне. Градостроители вынуждены ежедневно решать возникающие проблемы, отвечать на конкретные урбанизационные задачи, поэтому они призывают учесть «большое разнообразие видов городской среды Санкт-Петербурга, в том числе морфотипов жилой застройки» и решать судьбу центра под лозунгом «совершенствуя - не разрушать» [4]. Такой подход требует конкретной информации о ткани массовой застройки. Необходимо изучение реальных особенностей жилой среды, детальное исследование составляющих её кварталов - как это было сделано в Москве, где в 1980-е годы стали использовать понятие «морфотипов застройки» и опираться на количественные показатели их пространственной организации [5; 6].

\section{Две группы петербургских морфотипов}

Санкт-Петербург считается образцом «умышленного города». Его застройка, вплоть до конкретных деталей, направлялась прямыми административными указаниями, что подтверждают опубликованные обзоры регламентирующих документов $[7 ; 8]$. Анализ представленной информации приводит к выводу, что ключевую роль в формировании жилой застройки сыграл дифференцированный подход: параметры кварталов и земельных участков для территорий в городской черте и в пригородной зоне различались по определяющим показателям (табл. 1).

Законы о землепользовании консервировали конфигурацию и размеры парцелл, не допускали их расчленения и продажи по частям (до конца XIX века исключения были немногочисленны). Территории, межевание которых в XVIII веке было произведено по установкам пригородной зоны, с течением времени в неизменном состоянии включались в городскую черту. Бывшие огородные участки получали плотную застройку, но сохраняли свои границы. Две группы морфотипов сформировались в условияхустойчивого режима землепользования и отличия параметров городских объектов от зародившихся в предместьях.

Обращение к конкретному уровню отдельного квартала позволит уточнить представление о «завершённости» исторической среды. Этот термин правомерен, когда описывается отдельная постройка или небольшой градостроительный объект, но вызывает вопросы, если используется для оценки огромного живого градостроительного организма. Возможно, поэтому и представления о признаках «завершённости» разные. Б.М. Кириков считает среду петербургского центра «завершённой в силу её слитности и насыщенности» [3], а городской регламент признает незавершённой средой «слабо освоенную и неэффективно используемую территорию»². Вопрос имеет не только теоретическое значение. Его внимательное и детальное рассмотрение должно конкретизировать: что следует совершенствовать, а что необходимо сохранять.

\section{Регулярные (городские) морфотипы}

Регулярные (городские) морфотипы возникли в XVIII веке в ходе застройки Васильевского острова, а затем Адмиралтейской стороны. На рисунке 1 представлены характерные образцы (для выявления связей дворовых пространств с городским транспортным каркасом въезды во дворы выделены жёлтой линией).

На рисунке 1 A - фрагмент плана Васильевского острова, в 1732-1733 годы развивавший идею Д. Трезини. Намечалось разместить каждый квартал на собственном острове, окруженном со всех сторон каналами - городскими транспортными магистралями [9]. Внутренние связи на территории острова обеспечивала сеть переулков (на схеме выделены красными линиями). Эта схема развивала приемы застройки, которая сложилась на южном берегу Невы (рис. 1 С). Матрицу 1730-х годов можно считать предшественницей создаваемых норм (РНГП) для будущей квартальной застройки Москвы [10]. Две

${ }^{2}$ TCH 30-306-2002 Территориальные строительные нормы. Реконструкция и застройка исторически сложившихся районов Санкт-Петербурга. - СПб: Стройиздат СПб, $2003-71$ с.

Таблица 1. Характерные показатели исторической застройки Санкт-Петербурга в зависимости от местоположения территориальной единицы

\begin{tabular}{|c|l|l|}
\hline \multirow{2}{*}{ Планировочная единица } & \multicolumn{2}{|c|}{ Местоположение территориальной единицы } \\
\cline { 2 - 3 } & \multicolumn{1}{|c|}{ В городской черте } & \multicolumn{1}{|c|}{ В пригороде или предместье } \\
\hline Земельный участок & $\begin{array}{l}\text { - конфигурация прямоугольная; } \\
\text { - размеры унифицированы }\end{array}$ & $\begin{array}{l}\text { понфигурация прямоугольная и не- } \\
\text { - размеры различны }\end{array}$ \\
\hline Квартал & $\begin{array}{l}\text { - конфигурация прямоугольная; } \\
\text { - фронтальная застройка унифициро- } \\
\text { ванной высоты, непрерывная по контуру }\end{array}$ & $\begin{array}{l}\text { с конфествовавация определена трассами } \\
\text { - параметры лицевого фронта не регла- } \\
\text { ментировались }\end{array}$ \\
\hline
\end{tabular}


модели близки по структуре и количественным характеристикам: «урбан-блоки» площадью до 2,5 га образуют квартал площадью до 20 га («новое - это хорошо забытое старое»!).

Вариант использовался на начальном этапе застройки Васильевского острова, но после 1760-х годов от него отказались, поскольку были засыпаны существовавшие там каналы.

На рисунке 1 В показан вариант, который стал основным в городе со второй половины XVIII века, когда строительная активность переместилась на южный берег Невы. Габариты кварталов уменьшили, от внутриквартальных связей отказались. С ликвидацией переулков городской коммуникационный каркас потерял низовое звено. Уменьшились проницаемость и связность селитебной застройки. Признаки, которые определяют особенности морфотипов регулярного типа, приведены в таблице 2.

Как фиксирует таблица 2, особенностью регулярного петербургского морфотипа является большая протяжёность кварталов (300-500 метров между перекрёстками) при относительно небольшой глубине, рассчитанной на двухрядное наполнение парцеллами его территории. Такие габариты вызывали негативные эмоции у пешеходов уже в начале XIX

A

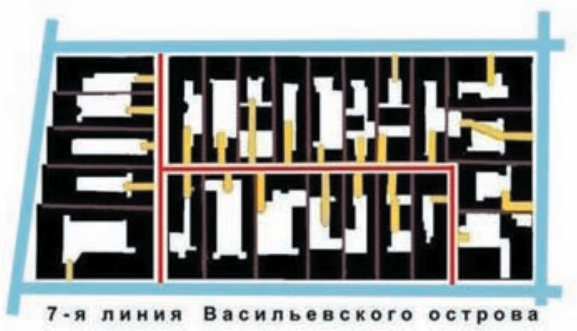

B

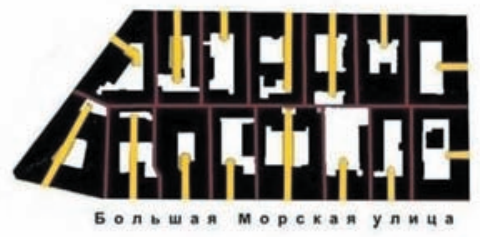

C

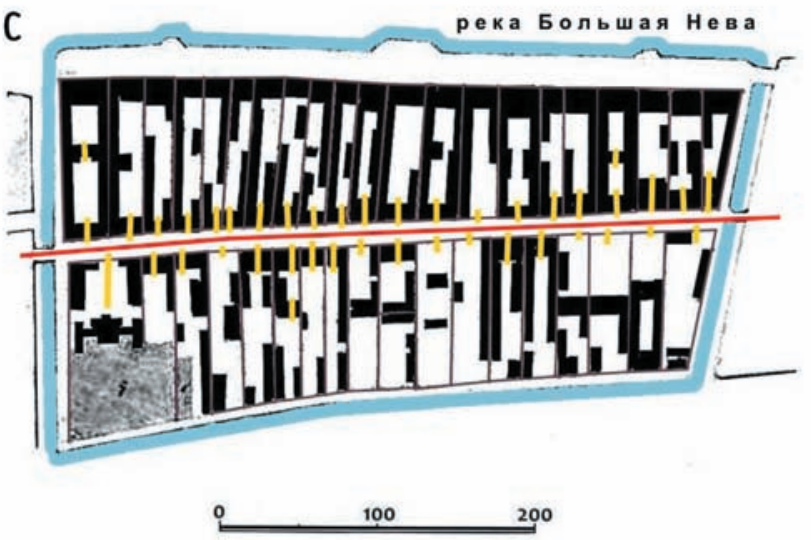

Рис. 1. Формирование морфотипа «регулярных» кварталов: $A$ - с использованием внутриквартальных связей, $B$ - с отсутствием внутриквартальных коммуникаций, C - прототип регулярного квартала на острове между Большой Невой и Адмиралтейским каналом
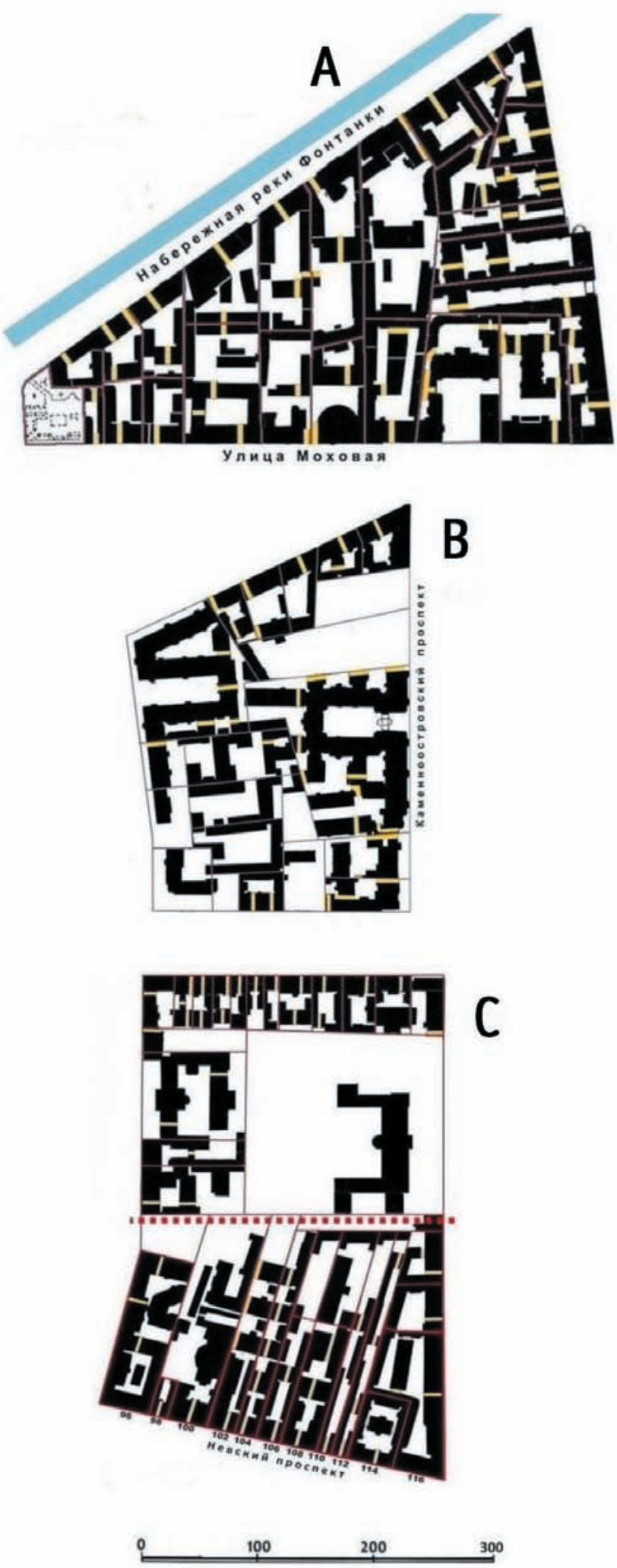

Рис. 2. Примеры «больших кварталов», сформировавшихся в эпоху доходного строительства: $A$ - между Фонтанкой и Моховой; $B$ - на углу Каменностровского проспекта и Большой Пушкарской улицы; C - на углу Невского проспекта и улицы Восстания 
века ${ }^{3}$ и обостряют критику по мере роста урбанизационной нагрузки на исторический центр [12].

Данные, представленные в таблице 2 позволяют на количественном уровне оценить завершённость пространственной организации квартала, используя для этого сведения о размерах пустот на его лицевой застройке и о наличии незастроенных участков: если в ядре центра кварталы выглядят как плотные монолиты, то на его периферии существуют пробелы - незастроенные площадки и пустыри на месте разрушенных в годы войны строений. Очевидно, что дальнейшие исследования должны учесть деформации, которые произошли при застройке кварталов регулярного морфотипа с отступлением от упорядоченных параметров «петербургского градострои-

${ }^{3}$ «Наводили тоску эти однообразные каменные громады, которые, как колоссальные гробницы, сплошною массою тянутся одна за другою. "Вот кончается улица, сейчас будет приволье глазам, - думал он, - или горка, или зелень, или развалившийся забор", - нет, опять начинается та же каменная ограда одиноких домов, с четырьмя рядами окон. И эта улица кончилась, её преграждает опять то же, а там новый порядок таких же домов. Заглянешь направо, налево - всюду обступили вас, как рать исполинов, дома, дома и дома, камень и камень, все одно да одно...» [12]. тельного кодекса», - нарушение границ парцеллы, требований «красной линии», «единого карниза», регламентов высоты.

Доходные «крупные кварталы сложной конфигурации»

Это обозначение, которое ввёл Н.И. Явейн [13], отражает начальный этап познания исторической жилой среды. Вероятно, со временем его заменит другой термин. Кварталы этой группы многообразнее кварталов регулярного морфотипа, но изучены ещё меньше, поэтому в настоящее время их специфика может быть рассмотрена лишь в первом приближении, а предложения по классификации сформулированы в общем виде.

Основная часть «больших кварталов» формировалась при территориальном расширении города с середины XIX века. Строительство велось в условиях, когда вся земля в предместьях уже обрела своих хозяев, а система землепользования закрепила крайне неоднородную ситуацию - места рядом с огромными массивами пригородных усадеб, казарменными комплексами и слободами казённых служителей были заняты небольшими огородными и дачными участками, территориями складов, кладбищ и различных коммунальных служб. Полагают, что и тогда «формирование или трансформация частей

Таблица 2. Морфология кварталов исторического центра Санкт-Петербурга

\begin{tabular}{|c|c|c|c|c|c|c|c|c|}
\hline \multicolumn{9}{|c|}{ Морфология кварталов исторического центра Санкт-Петербурга } \\
\hline & \multirow[b]{2}{*}{$\begin{array}{l}\text { Регулярный } \\
\text { морфотип }\end{array}$} & \multicolumn{3}{|c|}{$\begin{array}{l}\text { Планировочные параметры } \\
\text { квартала }\end{array}$} & \multirow{2}{*}{$\begin{array}{l}\text { Фасадный } \\
\text { фронт } \\
\text { Доля неза- } \\
\text { строенного } \\
\text { периметра } \\
\text { (\%) }\end{array}$} & \multicolumn{3}{|c|}{ Внутриквартальная среда } \\
\hline & & $\begin{array}{l}\text { Очерта- } \\
\text { ния } \\
\text { в плане }\end{array}$ & $\begin{array}{l}\text { Площадь } \\
\text { (га): } \\
\text { (а) - } \\
\text { макси- } \\
\text { мальная- } \\
\text { (в) - хара- } \\
\text { ктерная }\end{array}$ & $\begin{array}{l}\text { габариты и } \\
\text { периметр } \\
\text { (м): } \\
\text { (а) - макси- } \\
\text { мальные; } \\
\text { (б) -хара- } \\
\text { ктерные }\end{array}$ & & $\begin{array}{l}\text { Характерные } \\
\text { параметры } \\
\text { дворовых } \\
\text { участков: } \\
\text { (а) -конфи- } \\
\text { гурация; } \\
\text { (б)-протя- } \\
\text { жённость } \\
\text { фасада } \\
\text { по красной } \\
\text { линии (м) }\end{array}$ & $\begin{array}{l}\text { Количест- } \\
\text { во неос- } \\
\text { военных } \\
\text { участков } \\
\text { в квартале }\end{array}$ & $\begin{array}{l}\text { Наличие } \\
\text { внутри- } \\
\text { кварталь- } \\
\text { ных обще- } \\
\text { доступ- } \\
\text { ных ком- } \\
\text { муни- } \\
\text { каций }\end{array}$ \\
\hline B.1 & $\begin{array}{l}\text { Василеостров- } \\
\text { ский завершён- } \\
\text { ный }\end{array}$ & \multirow{4}{*}{$\begin{array}{l}\text { Прямоу- } \\
\text { гольник } \\
\text { (как } \\
\text { произ- } \\
\text { водные - } \\
\text { трапе- } \\
\text { ция, тре- } \\
\text { угольник) }\end{array}$} & \multirow{2}{*}{ (б) 6,3} & \multirow{2}{*}{$\begin{array}{l}(б)- \\
447,3 \times 140,6 \\
(1175 \mathrm{~m})\end{array}$} & 0 & \multirow{2}{*}{$\begin{array}{l}\text { (а) -прямоу- } \\
\text { гольник; } \\
\text { (б) } 12-21,3 \mathrm{M}\end{array}$} & 0 & \multirow{2}{*}{ Переулки } \\
\hline B.2 & $\begin{array}{l}\text { Василеостров- } \\
\text { ский незавер- } \\
\text { шённый } \\
\end{array}$ & & & & Более 10 & & $\begin{array}{l}2-3 n \\
\text { более }\end{array}$ & \\
\hline A.1 & $\begin{array}{l}\text { Адмиралтей- } \\
\text { ский завер- } \\
\text { шённый } \\
\end{array}$ & & \multirow{2}{*}{$\begin{array}{l}\text { (a) } 6,09 \text {; } \\
\text { (б) } 3,89 \text { и } \\
1,92\end{array}$} & \multirow{2}{*}{$\begin{array}{l}\text { (a) - } \\
553,8 \times 110,7 \\
(1330 \mathrm{~m}) ; ; \\
(6)- \\
277,9 \times 140,6 \\
(837 \mathrm{~m})\end{array}$} & 0 & \multirow{2}{*}{$\begin{array}{l}\text { (а) - прямоу- } \\
\text { гольник; } \\
\text { (в) } 25,6-42,6\end{array}$} & 0 & \multirow[b]{2}{*}{0} \\
\hline A. 2 & $\begin{array}{l}\text { Адмиралтей- } \\
\text { ский незавер- } \\
\text { шённый }\end{array}$ & & & & Более 10 & & $\begin{array}{l}2-3 \text { n } \\
\text { более }\end{array}$ & \\
\hline
\end{tabular}


(фрагментов) города протекали целенаправленно и планомерно, а отнюдь не стихийно и хаотично» [14]. Однако степень административного воздействия существенно уменьшилась и блокировалась соображениями доходного землевладения. Характер застройки на присоединённых к городу территориях стала определять игра цен на рынке недвижимости. Участки, которые удавалось приобрести для освоения, редко получали правильную прямоугольную форму, а трассы новых улиц не всегда были прямолинейными. Под воздействием рыночных отношений преобразуется строительное законодательство, и на осваиваемых территориях пригородов разрешают разделение участков застройки, допускается возможность отступить от застройки «сплошным фасадом» вдоль красной линии и устраивать мансарды над карнизами.

Процесс урбанизации требовал развития сети улиц и проездов, но сказывались и административно-юридические препоны, и недостаток городских средств на выкуп необходимых земельных участков. Под давлением множества обстоятельств новые кварталы редко приобретают чёткие прямоугольные очертания. С трудом находятся деньги, позволившие связать с Невским тупиковую Надеждинскую (ныне - улицу Маяковского) и Слоновую улицы (ныне Суворовский проспект). К градостроительной деятельности подключаются деловые люди, заинтересованные в освоении под доходную застройку привлекательных площадок в оживлённых частях города: за счёт частного капитала сквозь огородные поля прокладывают Пушкинскую улицу, продлевают магистраль Большого проспекта на Петроградской стороне (здесь сказалось веяние модерна, и трасса приобрела скруглённые очертания). Тем не менее развитие транспортного каркаса Санкт-Петербурга (особенно на вновь присоединённых территориях) отставало от темпов территориального роста города. Кварталы больших размеров стали характерным признаком городской среды, сложившейся в 1840-1918 годы.

Квартал, показанный на рисунке 2 A, примыкает к южному берегу Фонтанки и расположен в той части города, которая осваивалась в первую очередь. Его развитие - редкий пример отступления от положений «генетического кода» СанктПетербурга. Межевание участков провели ещё в первой половине XVIII века, начали строить деревянные дома вдоль Моховой улицы, но дальнейшую застройку задержала заболоченность почв. Когда в конце XVIII века была построена гранитная набережная Фонтанки, изменились нечёткие очертания топкого берега, и было решено пересмотреть границы участков застройки (редчайший случай в практике города), из-за чего многие парцеллы потеряли прямоугольную форму. Фронт корпусов вдоль Фонтанки появился в первой трети XIX века, после 1840-х годов на Моховой улице деревянные строения заменили капитальными, и облик квартала приблизился к образцам регулярной застройки. В конце XIX века жандармское управление освобождает занимаемые им участки на Пантелеймоновской улице (ныне улица Пестеля), и тут же вдоль лицевого фронта появляются постройки, характерные для нового этапа развития города, - огромных размеров, с использованием курдонеров. Формирование квартала было завершено уже в советские годы с появлением двух угловых зданий на берегу Фонтанки. Этот квартал может считаться примером морфотипа «переходного типа».

Контур квартала, изображённого на рисунке 2 В, был очерчен в начале XIX века, когда просёлочные дороги прокладывали сквозь огороды, занимавшие эту часть Петроградской строны. Активную застройку начали в конце XIX - начале XX века, когда был построен Троицкий мост, и Каменноостровский проспект стал оживлённой магистралью. Появившаяся среда отразила возможности, которые давало обновление нормативов. На лицевом фронте видны глубокие курдонеры, значительная часть застройки отступает от «красной линии» и оставляет полоску длинных палисадников. Разнообразна внутриквартальная среда - участки не унифицированы, они резко различаются по размерам и конфигурации. Застройку квартала нельзя считать завершённой - к 1918 году два участка были не освоены, обширный пустырь остался открытым в сторону проспекта.

Квартал на рисунке 2 C - пример адаптации огромной усадьбы «Итальянский сад», которая возникла при Петре I и широкой полосой тянулась от Фонтанки до Лиговского канала. В процессе урбанизации её последовательно рассекли на три части. В 1850-е годы намечали проложить ещё одну улицу (намечаемая трасса показана красным пунктиром), но не нашли денег на выкуп земли [15]. Город рос, и под жилую застройку передали полоски земли вдоль Малой Итальянской (ныне - Жуковского) улицы и Невского проспекта. Осваиваемая площадка у Невского проспекта отличалась большой глубиной, что повлияло на межевание: участки на красной линии имеют по 12 м, а вглубь тянутся более чем на 100 м. Посредине квартала сохранялась обширная пустынная полоса. В середине XIX века на этой земле построили приют и родильный дом, но их появление носило случайный характер и не повысило связность застройки. Городская ткань воспринималась здесь не завершённой ни в функциональном, ни в композиционном отношении, поэтому в 1990-е годы предприняли локальную реконструкцию - по намеченной в 1850 годы трассе проложили пешеходную аллею, а вдоль неё разместили многофункциональный комплекс. $K$ новой коммуникации подключились бывшие тупиковые дворы, что вдохнуло жизнь в депрессивную лакуну городского центра. Сейчас наследием «Итальянских садов» остался квартал 130, занимающий территорию в 13,5 га.

Приведённые примеры позволяют заключить, что застройка, осуществлённая в Санкт-Петербурге во второй половине XIX - начале XX века, привела к формированию весьма разнообразной городской среды, и каждый из возникших кварталов обладает значительными функционально-планировочными особенностями. Их классификация требует дальнейшей проработки и должна дополнить общеустановочные сведения о квартале (конфигурация, общая площадь, габариты) информа- 
цией о его специфических чертах, касающейся особенностей лицевой застройки (А) и внутриквартальных пространств (B):

A-особенности лицевой застройки:

А.1 - доля лицевого фронта традиционного типа («под единый карниз и сплошным фасадом»);

А.2 - наличие и значимость отклонений от традиционных установок (доля лицевой застройки, отступающей от красной линии, наличие разрывов между лицевыми фасадами и зданий, высота которых превышает отметку карниза Зимнего дворца).

\section{B - внутриквартальные пространства:}

В.1 - доля парцелл унифицированного формата (прямоугольные очертания, заданные габариты, фиксация границ брандмауэрами);

В.2 - разброс в параметрах домовых участков (по конфигурации и по площади), фиксирующий наличие и размеры участков бывших усадеб или полковых дворов;

В.3 - наличие неосвоенных участков.

\section{8-2018. Завершённость}

Городскую среду петербургского центра, доставшуюся нам в наследство, предлагают «считать завершённой в силу её слитности и насыщенности» [8]. Такая оценка правомочна на стратегическом уровне, но требует уточнения, обращения к конкретным особенностям кварталов.

Формирование городской среды исторического центра «завершилось (или оборвалось) сто лет назад, после чего она не подвергалась кардинальным изменениям» [8]. К моменту, когда замер градостроительный процесс в центре Петрограда,

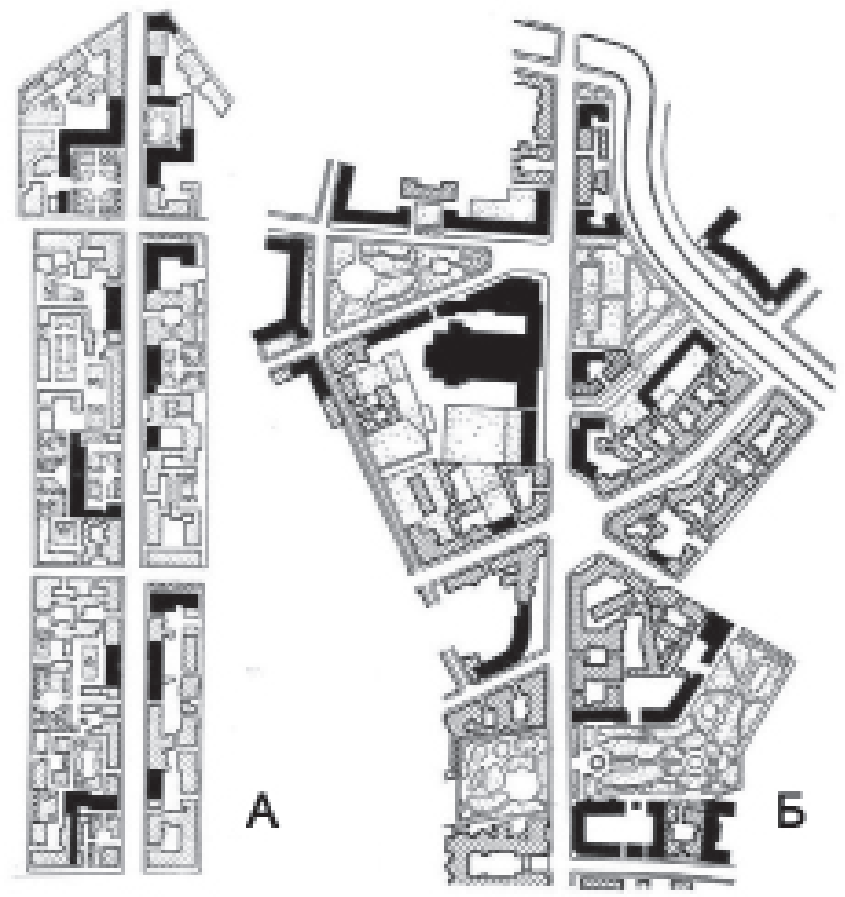

Рис. 3. Градостроительное завершение жилых кварталов Петроградской строны в 1930-1960-е годы: A -участок вдоль улицы Ленина; $B$ - участок возле площади Льва Толстого жилищный фонд города позволял расселить около 2 млн человек. Примерно 500 тыс. проживали в ядре города, кварталы которого уже прошли большой путь развития - на протяжении двухсот лет они достраивались, реконструировались, уплотнялись. Большую часть жилищного фонда составляли молодые или очень молодые кварталы, появившиеся в 1891-1914 годах и обеспечившие прирост населения с одного до двух миллионов человек. С началом Первой мировой войны строительные работы начали тормозиться, а в 1918 году всё замерло. В новых кварталах оставались неосвоенные участки, некоторые здания стояли в лесах. Остались на полках многие проекты.

В годы гражданской войны и послевоенной разрухи состояние недостроенных корпусов ухудшилось, но с середины 1920-х годов их судьба стала привлекать внимание. Ленинград тогда уже рассматривался как город с «областной судьбой», его градостроительные амбиции финансовой поддержки не получали. Тем не менее был взят курс на ликвидацию пробелов в структуре жилых кварталов. Начало было положено в 1927 году, когда завершили формирование жилого квартала Бассейнового товарищества собственников квартир, для чего по проекту Е.А. Левинсона достроили корпус по Виленскому переулку.

Строительная программа, реализованная в 1930-1960е годы, повысила завершённость застройки центральных районов. Рисунок 3 показывает, как увеличилась слитность дореволюционных жилых кварталов на Петроградской стороне. Объёмно-планировочные параметры возводимых построек (они выделены чёрным цветом) ориентировались на положения петербургского «генетического кода» - как при размещении здания в плане, так и при определении его высоты. Тот факт, что в 1990 году эти кварталы стали частью объекта Всемирного наследия ЮНЕСКО «Исторический центр Санкт-Петербурга и связанные с ним группы памятников», свидетельствует о положительном восприятии такого подхода в России и на мировом уровне.

$$
\text { *** }
$$

Проведённый краткий экскурс в историю формирования петербургской жилой среды позволил высказать первые предложения по определению характерных для исторического центра морфотипов. Эта работа должна быть продолжена с охватом большей территории и конкретизацией сформулированных предложений.

Рассмотрение частного вопроса о степени завершённости исторической среды Санкт-Петербурга продемонстрировало, что существенный вклад был внесён в её развитие после 1918 года и подтвердило продуктивность ориентации на лозунг «совершенствуя, не разрушать».

Выявилась необходимость критического рассмотрения оценки, которую исторической среде дают Территориальные строительные нормы. В обширной цитате курсивом выделены положения, которые требуют особого внимания: «Исторический центр города (средовые районы: 1-149) характеризуется наиболее высокой градостроительной за- 
вершённостью и историко-культурной ценностью среды, интенсивностью использования территории и разнообразием функций... Основная застройка ИЦ сформирована капитальными многоэтажными домами постройки второй половины XIX - начала XX в. Онахарактеризуется высокой плотностью улично-дорожной сети, небольшими размерами кварталов, высокой плотностью и равномерной этажностью застройки, единством модуля застройки, её периметральностью, компактностью внутриквартальных пространств и развитостью внутриквартальных пешеходных трасс» ${ }^{4}$.

${ }^{4} \mathrm{TCH}$ 30-306-2002 Территориальные строительные нормы. Реконструкция и застройка исторически сложившихся районов Санкт-Петербурга. - СПб: Стройиздат СПб, 2003 - 71 с.

\section{Лuтература}

1. Уточнение границ исторического центра СанктПетербурга [Электронный ресурс] // Союз реставраторов Санкт-Петербурга. - Режим доступа: http://srspb.ru/article. php?id=207\&mode=ar (дата обращения 15.07.2017).

2. Нераскрытый Петербург. Исследование потенциала урбанизированной территории Санкт-Петербурга [Электронный ресурс] // MLA+. - Режим доступа: https://www.mlaplus.com/ wp-content/uploads/2019/02/Densification-possibilities-forSt.Petersburg.pdf (дата обращения 15.08.2019).

3. Кириков, Б.М. Архитектура Петербурга-Ленинграда / Б.М. Кириков. - СПб : Коло, 2014. - 400 с.

4. Николащенко, Б.В. Двенадцать принципов практического градостроительства в Санкт-Петербурге от старожила улицы Зодчего Росси (памяти В.Ф. Назарова) / Б.В Николащенко // Архитектурный Петербург - 2015. - № 5.

5. Гутнов, А.Э. Эволюция градостроительства / А.Э. Гутнов - М. : Стройиздат, 1984. - 297 с.

6. Кожаева, Л.Б. Морфотипы застройки центра Москвы / Л.Б. Кожаева // Архитектура СССР. -1987. - № 09-10. - С. 102-107.

7. Семенцов, С.В. Этапы формирования пространственной среды Санкт-Петербурга. Ч.1. Историческое развитие кварталов и их регламентация / С.В. Семенцов // Вестник гражданских инженеров. - 2006. - № 2 (7). - С. 15-20.

8. Семенцов, С.В. Этапы формирования пространственной среды Санкт-Петербурга. Ч. 2. Историческое развитие участков (системы разбивки и застройки участков) и их регламентация. / С.В. Семенцов // Вестник гражданских инженеров.- 2006. - № 3 (8). - С. 21-26.

9. Борисова, E.A. Работы Доменико Трезини по планировке и застройке Стрелки Васильевского острова в Петербурге / Е.А. Борисова // Русское искусство века. Материалы и исследования. - М. - 1973. - С. 20-37.

10. Матрица для квартальной застройки [Электронный ресурс] // Интерфакс-недвижимость. - Режим доступа: https://archsovet.msk.ru/pressa/elektronnye-smi/matricadlya-kvartal-noy-zastroyki (дата обращения 10.08.2019).
11. Гончаров, И.А. Обыкновенная история. / И.А. Гончаров // Собрание сочинений в восьми томах. Т. 1. - М. : Государственное издательство художественной литературы, 1952.

12. Линов, В.К. Проблемы развития общественных пространств в историческом центре Санкт-Петербурга. / В.К. Линов // Вестник гражданских инженеров. - 2012. - № 4 (33). - С. 42-47.

13. Внутренний Петербург [Электронный ресурс] // Archplatforma.ru. - Режим доступа: http://archplatforma. ru/?act=2\&tgid=1558\&stchng=2 (дата обращения 26.03.2017).

14. Кириков, Б.М. Архитектура Петербурга конца XIX -начала XX века: Эклектика. Модерн. Неоклассицизм. / Б.М. Кириков. - СПб : Коло, 2008. - 448 с.

15. Арутюнян, Ю.И. Утраченные парки Санкт-Петербурга: роль Итальянского сада в застройке Литейной части. / Ю.И. Арутюнян // Вестник Санкт-Петербургского государственного университета культуры и искусств. - 2017. - № 2 (31) июнь. - C. 177-181.

\section{References}

1. Utochnenie granits istoricheskogo tsentra SanktPeterburg [Elektronnyj resurs] [Clarification of the boundaries of the historical center of St. Petersburg]. Soyuz restavratorov Sankt-Peterburga [Union of restorers of St. Petersburg]. URL: http://srspb.ru/article.php?id=207\&mode=ar (accessed 15.07.2017). (In Russ.)

2. Neraskrytyi Peterburg. Issledovanie potentsiala urbanizirovannoi territorii Sankt-Peterburga [Elektronnyj resurs] [Undisclosed Petersburg. Study of the potential of the urbanized territory of St. Petersburg]. MLA+. URL: https://www. mlaplus.com/wp-content/uploads/2019/02/Densificationpossibilities-for-St.-Petersburg.pdf (Accessed 15.08.2019). (In Russ.)

3. Kirikov B.M. Arkhitektura Peterburga-Leningrada [Architecture of St. Petersburg-Leningrad]. Saint-Petersburg, Kolo Publ., 2014, 400 p. (In Russ.)

4. Nikolashchenko B.V. Dvenadtsat' printsipov prakticheskogo gradostroitel'stva $\vee$ Sankt-Peterburge ot starozhila ulitsy Zodchego Rossi (pamyati V.F. Nazarova) [The twelve principles of practical urban development in St. Petersburg from an oldtimer of the street of the Architect Rossi (in memory of V.F. Nazarov)]. Architecturnyy Peterburg [Architectural Petersburg], 2015. - no. 5. (In Russ.)

5. Gutnov A.E. Evolyutsiya gradostroitel'stva [The evolution of urban development]. Moscow, Stroiizdat Publ., 1984, 297 p. (In Russ.)

6. Kozhayeva L.B. Morfotipy zastroiki tsentra Moskvy [Building morphotypes of the center of Moscow]. Arkhitektura SSSR [USSR architecture],1987no. 09-10, pp. 102-107. (In Russ.)

7. Sementsov S.V Etapy formirovaniya prostranstvennoi sredy Sankt-Peterburga. Ch.1. Istoricheskoe razvitie kvartalov $\mathrm{i}$ ikh reglamentatsiya [Stages of the formation of the spatial environment of St. Petersburg. Part 1. Historical development of 
quarters and their regulation]. Vestnik grazhdanskih inzhenerov [Bulletin of Civil Engineers], 2006, no. 2 (7), pp. 15-20. (In Russ., abstr. in Engl.)

8. Sementsov S.V. Etapy formirovaniya prostranstvennoj sredy Sankt-Peterburga. Ch. 2. Istoricheskoe razvitie uchastkov (sistemy razbivki i zastrojki uchastkov) i ih eglamentatsiya [Stages of the formation of the spatial environment of St. Petersburg. Part 2. Historical development of sites (system of sectoring and development of sites) and their regulation]. Vestnik grazhdanskih inzhenerov [Bulletin of Civil Engineers], 2006, no. 3 (8). Pp. 21-26. (In Russ., abstr. in Engl.)

9. Borisova Ye.A. Raboty Domeniko Trezini po planirovke i zastroyke Strelki Vasil'yevskogo ostrova v Peterburge [Domenico Trezzini's work on the planning and development of the Spit of Vasilyevsky Island in St. Petersburg]. Russkoye iskusstvo veka. Materialy $i$ issledovaniya [Russian art of the century. Materials and research]. Moskva, 1973, pp. 20-37

10. Matritca dlya kvartal'noj zastrojki [Elektronnyj resurs] [The matrix for quarterly development]. Interfaks-nedvizhimost' [Interfax Real Estate]. URL: https://archsovet.msk.ru/pressa/elektronnyesmi/matrica-dlya-kvartal-noy-zastroyki (Accessed 25.07.2019).

11. Goncharov I.A. Obyknovennaya istoriya [Ordinary story]. Sobraniye sochineniy $v$ vos'mi tomakh [Collected Works in eight volumes], Vol. 1. Moscow, Gosudarstvennoye izdatel'stvo khudozhestvennoyliteratury Publ., 1952.

12. Linov, V.K. Problemy razvitiya obshchestvennykh prostranstv $v$ istoricheskom tsentre Sankt-Peterburga. [Problems of the development of public spaces in the historical center of St. Petersburg] Vestnik grazhdanskih inzhenerov, 2012, no. 4 (33), pp. 42-47.

13. Vnutrenniy Peterburg [Elektronnyj resurs] [Inner Petersburg]. Archplatforma.ru. URL: http://archplatforma. ru/?act=2\&tgid=1558\&stchng=2 (accessed 26.03.2017).

14. Kirikov, B.M. Arkhitektura Peterburga kontsa XIX - nachala XX veka: Eklektika. Modern. Neoklassitsizm. [Architecture of St. Petersburg at the end of the XIX - beginning of the XX century: Eclecticism. Modern. Neoclassicism]. St. Petersburg, Kolo Publ., 2008, 448 p.

15. Arutyunyan, YU. I. Utrachennyye parki Sankt-Peterburga: rol' Ital'yanskogo sada v zastroyke Liteynoy chasti [Lost parks of St. Petersburg: the role of the Italian garden in the development of the Liteiniy district]. Vestnik Sankt-Peterburgskogo gosudarstvennogo universiteta kul'tury $i$ iskusstv [Vestnik of Saint-Petersburg State University of Culture], 2017, no. 2 (31), pp. 177-181.

Лавров Леонид Павлович (Санкт-Петербург). Доктор архитектуры, профессор, член-корреспондент РААСН, член-корреспондент Германской академии градостроительства и планирования земель. Профессор-консультант ФГБОУ В0 «Санкт-Петербургский государственный архитектурно-строительный университет» (190005, Россия, Санкт-Петербург, 2-я Красноармейская ул., 4. СПбГАСУ). Эл.почта:Leonid.lavrov@gmail.com.

Молоткова Елена Геннадьевна (Санкт-Петербург). Кандидат архитектуры, доцент. Заведующий кафедрой рисунка ФГБоУ В0 «Санкт-Петербургский государственный архитектурно-строительный университет (190005, Россия, Санкт-Петербург, 2-я Красноармейская ул., 4. СПбГАСУ). Эл. почта: elena2255@yandex.ru.

Перов Федор Викторович (Санкт-Петербург). Кандидат архитектуры, доцент. Декан архитектурного факультета ФГБоУ в0 «Санкт-Петербургский государственный архитектурно-строительный университет (190005, Россия, Санкт-Петербург, 2-я Красноармейская ул., 4. СПбГАСУ). Эл. почта: f.perov@gmail.com.

Lavrov Leonid Pavlovich (St. Petersburg). Doctor of Architecture, Professor, Corresponding Member of RAACS, Corresponding Member of the German Academy of Urban and Land Use Planning (DASL). Professor-Consultant at the Saint Petersburg State University of Architecture and Civil Engineering (4 2nd Krasnoarmeyskaya st,, St. Petersburg, Russia, 190005. SPSUACE). E-mail: leonid.lavrov@gmail.com.

Molotkova Elena Gennadievna (St. Petersburg). Candidate of Architecture, Associate Professor. Head of the Department of Drawing at the Saint Petersburg State University of Architecture and Civil Engineering (4 2nd Krasnoarmeyskaya st., St. Petersburg, Russia, 190005. SPSUACE).E-mail: elena2255@yandex.ru.

Perov Fedor Viktorovich (St. Petersburg). Candidate of Architecture, Associate Professor. Dean of the Faculty of Architecture of Petersburg State University of Architecture and Civil Engineering, head of the Department of Architectural Design at the Saint Petersburg State University of Architecture and Civil Engineering (4 2nd Krasnoarmeyskaya st., St. Petersburg, Russia, 190005. SPSUACE).E-mail: f.perov@gmail.com. 